\title{
MORPHOAGRONOMIC CHARACTERS AND PARTIAL RESISTANCE TO SOYBEAN RUST IN EARLY SOYBEAN GENOTYPES.
}

\author{
CARACTERES MORFOAGRONÔMICOS E RESISTENNCIA PARCIAL À FERRUGEM \\ ASIÁTICA EM GENÓTIPOS PRECOCES DE SOJA
}

\author{
Morony Martins OLIVEIRA ${ }^{1}$; Fernando Cezar JULIATTI ${ }^{1,2}$. \\ 1. Mestre em Agronomia, Universidade Federal de Uberlândia - UFU, Uberlândia, MG, Brasil. morony91 @ gmail.com. 2. Professor \\ Titular da UFU. Pesquisador 1D do CNPq. juliatti@ufu.br.
}

\begin{abstract}
Soybean crop, despite the technological evolution, did not reach an average of $4,000 \mathrm{~kg}$ ha-1 in Brazil due to the factors of climate, nutritional and soil fertility, genetics and phytosanitary problems. Among them is the rust-soy disease of soybean, caused by the fungus Phakopsora pachyrhizi Syd. \& Syd., one of the most severe, with damage up to $100 \%$. Among the management strategies are the use of early genotypes, use of preventive fungicides and cultivars with partial resistance and tolerant to phytopathogen. To obtain resistant cultivars, six dominant genes that condition vertical (qualitative) resistance, have already been reported in the literature, but the stability of this type of resistance is not durable. Therefore, the identification of genotypes that can be used as sources of horizontal (quantitative) resistance is essential to increase the longevity of the cultivars launched in the Brazilian market. This work aimed to evaluate the resistance of 12 soybean genotypes to the pathogen and yield responses. This work was developed at Fazenda do Glória, in Federal University of Uberlândia (UFU), located in the city of Uberlândia, MG, Brazil. In the agricultural year 2015/2016 an experiment was carried out with subplots with or without fungicide Azoxistrobina + Benzovindiflupyr and subsubplots related to the evaluation position in the plant. There were 12 early-cycle genotypes, 10 from the UFU germplasm laboratory (LAGER), a commercial susceptible control, and a known resistant LAGER control. They were outlined in randomized blocks with four replicates. The experimental plots were represented by two rows of $6 \mathrm{~m} \mathrm{x} 0.5 \mathrm{~m}$, and the $2.5 \mathrm{~m} 2$ area consisted of the two central rows, eliminating $0.5 \mathrm{~m}$ at each end of the plot. The LAGER-210 and LAGER-216 genotypes were selected for crop and use value (CUV) studies because they showed partial resistance to rust, short cycle, good morphoagronomic characteristics and higher yields.
\end{abstract}

KEYWORDS: Glycine max. Plant Breeding. Phakopsora pachyrhizi. Glycine max (L.) Merrill. Soybean Breeding. Phakopsora pachyrhizi. Genetic Control.

\section{INTRODUCTION}

Agriculture is since the colonial period one of the most important sectors of the Brazilian economy. Currently, among the species of cultivated plants, the soybean crop [Glycine max (L.) Merrill] stands out both in Brazil and in the world. The main use of soybean is the production of oil and bran, mainly in addition to the consumption in natura on a lesser scale of commercialization. As soybean bran is source of inexpensive and quality protein, this product is one of the most important in animal rations. Soybean oil is the most important vegetable oil consumed in the world and its demand should increase because of the growth of the use of renewable fuels, such as biodiesel.

This growth of soybean demand reflects in the production rate. Expectation for the 2016/2017 soybean harvest is pointing to record highs. According to the latest estimates by the Brazilian government, this year's harvest should grow by $19.5 \%$ compared to $2015 / 2016$ to reach 114.04 million tons. Soybean planted area for 2016/2017 is estimated at a record high 33.92 million hectares, up 2 percent from last year (COMPANHIA NACIONAL DE ABASTECIMENTO - CONAB, 2017).

In view of the major importance of soybean for Brazilian agribusiness, researches about the factors that limit the maximum expression of productivity are necessary. Among the main challenges encountered, the diseases have a prominent role. Approximately 40 diseases have been observed in Brazil, by the full range of pathogenic agents including fungi, bacteria, nematodes and viruses (EMBRAPA, 2014). 
Morphoagronomic characters...

According to estimates, annual production losses by this factor can reach $20 \%$ and in some specific conditions almost $100 \%$. The economic importance of each disease varies between years and between regions, depending on the climatic conditions of each harvest. Among the major soybean diseases, soybean rust has the highest importance.

The soybean rust is caused by the fungus Phakopsora pachyrhizi Syd. \& P. Syd., and arrived in South America in 2001. After the initial detection of $P$. pachyrhizi, soybean rust spread quickly into important soybean production regions in Brazil (YORINORI; LAZZAROTTO, 2004). The disease manifested highly aggressively primarily by generating early defoliation, which negatively influences the formation and granulation of the pods and in the final weight of the grains. The earliest defoliation occurs, the smaller grain size and hence the greater the loss of yield and quality (DALLA LANA et al., 2015). Currently, the chemical control is the main technique for reducing the damage caused by the pathogen. On average, they are made from two to three applications of fungicide by harvest, which elevates the production cost of culture (SCHWERZ et al., 2016). Other management techniques have been used by the main soybean production zones in the country, in order to reduce the number of fungicides applications. One of these techniques is the "fallowing", a legislative tecnique which, through normative instructions of each State, prohibits the cultivation of soybeans in the period of off season and demands the destruction of voluntary plants in places of cultivation (SEIXAS; GODOY, 2007). This technique aims to decrease the effect of the "green bridge" thus leads to reduction of the initial inoculum of the pathogen in order to delay, as much as possible, the beginning of the epidemic.

Another management technique is the use of early cycle cultivars, with sowing at the beginning of the cultivation season. In this way, the onset of the epidemic, delayed by the decrease of the initial inoculum caused by the "fallowing" will be only verified when the plants are already at an advanced stages of development, with most of the productivity already guaranteed. In these circumstances, fungicides are more effective and require fewer amounts of sprays.

In addition, the genetic resistance to soybean rust is a fundamental component of integrated management for the sustainable disease control, both from cost-benefit to the farmer and from the environmental standpoint. Some major genes that
OLIVEIRA, M. M.; JULIATTI, F. C.

control resistance to soybean rust have been identified (LI et al., 2012). However, there is evidence that the causal agent of the rust presents high variability (AKAMATSU et al., 2013; KATO; YORINORI, 2008). Due to the risk of vertical resistance breaking, the targeting of genetic improvement programs to obtain partial resistance genotypes becomes feasible, not just as isolated strategy but in combination with other forms of resistance. A strategy to evaluating partial resistance sometimes is confused with tolerance. The use of the both strategies has been the use of management with different types of fungicides to compare genotypes in the presence and absence of rust, estimating the rust effect (losses caused by rust) based on grain yield (CARNEIRO, 2007).

This work aimed to evaluate the partial resistance to soybean rust and the morfoagronomics characters of different soybean genotypes under field conditions, subjected to chemical control.

\section{MATERIAL AND METHODS}

The experiment was carried out during the 2015/2016 harvest at Fazenda do Glória, a research station of the Universidade Federal of Uberlândia, between the geographical coordinates $18^{\circ} 57 \mathrm{~S}$; $48^{\circ} 12^{\prime} \mathrm{W}$ and $860 \mathrm{~m}$ of altitude, in Uberlândia, Minas Gerais state, Brazil. The soil characterization was Latossolo Vermelho-Amarelo (Brazilian classification system). The preparation of soil was based on a conventional tillage, with one plowing and two harrowings.

The maximum and minimum daily temperatures $\left({ }^{\circ} \mathrm{c}\right)$, precipitation $(\mathrm{mm})$ and relative humidity $(\%)$, were collected electronically from an meteorological station of INMET (Instituto de Nacional de Meteorologia) located in the same research center, corresponding an approximate interval of 90 days, representing the period of installation and evolution of the disease at host plant.

Twelve soybean genotypes (table 1) were evaluated, and of these, ten were lineages proceeding from the Germplasm Development Laboratory of Universidade Federal de Uberlândia, one susceptible commercial cultivar (BRX DESAFIO 8473 RSF) and one know resistance genotype by Germplasm Development (LAGER-216). Two row of soybean plants with six meters long and row spacing of $0.5 \mathrm{~m}$ formed the plots. The seeds were not submitted to inoculation or treatment with agricultural pesticides. 
Table 1. Soybean genotypes and their respective pedigrees. Uberlândia, UFU, 2015

\begin{tabular}{ll}
\multicolumn{1}{c}{ Genotypes } & Genotypes pedigree \\
\hline LAGER-218 & F8 BRSGOLuziânia X UFUSImpacta \\
LAGER-266 & F8 BRSGOCaiapônia X Potenza \\
LAGER-144 & F8 BRSGOCaiapônia X IAC100 \\
LAGER-166 & F8 BRSGOCaiapônia X IAC100 \\
LAGER-104 & F8 BRSGOLuziânia X UFUSImpacta \\
LAGER-203 & F8 BRSGOLuziânia X Potenza \\
LAGER-224 & F8 BRSGOLuziânia X Potenza \\
LAGER-268 & F8 BRSCaiapônia X Potenza \\
LAGER-210 & F8 BRSGOLuziânia XUFUS Impacta \\
LAGER-279 & F8 BRSGOCaiapônia X Potenza \\
LAGER-216 (resistance) & F8 BRSGOLuziânia X Potenza \\
BRX DESAFIO 8473 & RSF \\
(susceptible) & - \\
\hline
\end{tabular}

Cultural and phytosanitary treatment were conducted in maintaining culture. Held manual weeding between rows to control weeds. At the reproductive stage R1 (beginning of flowering) the fungicide Azoxystrobin + Benzovindiflupir was applied, at a dose of $0.25 \mathrm{~kg} \mathrm{ha}^{-1}$, with spray volume of $200 \mathrm{~L} \mathrm{ha}^{-1}$. For the application, CO2 costal pump (pressure of 40 pounds pol-2 and tips TT 110.03), equipped with $3 \mathrm{~m}$ bar, fan-type spray tip M034, and $200 \mathrm{~L} \mathrm{ha}^{-1}$ spray volume was used. The fungicide spraying was done without wind to avoid fungicide derive. During the whole crop cycle, four evaluations were conducted by respecting the average interval of 10 days each, at 51, 61, 71 and 81 days after emergence (DAE). The evaluations consisted in checking the disease severity with diagrammatic scale (POLIZEL; JULIATTI, 2010). Nine trefoils per subsubplot were evaluated, collected in the middle third and upper third of the plant, randomly in the area of the subplot, i.e. in the two central rows.

From the severity data, the area under the disease progress curve (AUDPC) was calculated. Through this system it is possible to establish a quantified the curve disease "versus" time. The AUDPC was calculated according to the formula used by Shanner and Finley (1977):

$$
A U D P C=\sum\left[\frac{(Y i+Y 1+1)}{2}\right] *(T i+1-T i)
$$

curve;

AUDPC $=$ area under the disease progress

$\mathrm{Yi}=$ rust severity $(\%)$ in the $\mathrm{i}$-th observation;

$\mathrm{Ti}=$ time (days) in the $\mathrm{i}$-th observation.
The agronomic performance of soybean genotypes was evaluated based on the following characters of five randomly plants at the subplot:

a) Number of days to flowering (NDF): corresponds to the number of days from seedling emergence to flowering. According to the phenological staging scale of Fehr and Caviness (1977), NDF is the phenological stage symbolized by $\mathrm{R} 1$ and defined as $50 \%$ of the plants with an open flower on the main stem.

b) Number of days to maturity (NDM): considered the number of days between emergences to the grain physiological maturity in the field, defined by $50 \%$ of plants with $95 \%$ of mature pods, symbolized as the phenological stage R8.

c) Plant height at flowering (PHF): at the beginning of flowering (R1 stage), five plants were evaluated at random in each plot, measuring the plant height with a metric ruler help, which consists in the height between the soil surface and the main stem apex of each plant.

d) Plant height at maturity (PHM): in physiological maturity stage of the grains (R8 stage), five plants at random were measured with a metric ruler help, considering the distance between the soil surface and the main stem apex of each plant.

e) Insertion height of the first pod (IHFP): stands for the distance $(\mathrm{cm})$ from the soil surface to the insertion point of first pod on the plant main stem. This trait was evaluated in five plants at random in each plot with a metric ruler help.

f) Yield: the plants of plot floor area were harvested and threshed manually. The mass of the harvested and threshed grains was determined with an electronic precision balance help. The grain mass value was converted, according to the previous 
Morphoagronomic characters...

results, to esteem the productivity in $\mathrm{kg} \mathrm{ha}^{-1}$ of each genotype, and adjusting the seed mass to $13 \%$ moisture.

The statistical analyses were conducted using the GENES software (CRUZ, 2013), Assistat (SILVA; AZEVEDO, 2016) and Microsoft Office Excel $®$ 2016. AUDPC and agronomic characters were submitted to analysis of variance (F-test and significant at 0.05 ) and the averages clustered through Scott-Knott test at a 0.05 level of
OLIVEIRA, M. M.; JULIATTI, F. C.

significance. Pearson correlation coefficients (r) were also calculated among characteristics.

\section{RESULTS AND DISCUSSION}

There was no triple interaction between genotype factors, fungicide application and plant position, at 0.01 significance level (table 2). However, significant double interactions were verified between genotypes $\mathrm{x}$ plant position, and plant position $\mathrm{x}$ application.

Table 2. The analysis of variance of the area under the disease progress curve (AUDPC)

\begin{tabular}{lllll}
\hline \multicolumn{1}{c}{$\mathrm{FV}^{*}$} & $\mathrm{DF}$ & $\mathrm{SS}$ & $\mathrm{MS}$ & $\mathrm{F}$ \\
\hline Blocks & 3 & 353203,93317 & 117734,64439 & $2,4286 \mathrm{~ns}$ \\
$\mathrm{Ta}^{1}$ & 11 & 4364366,68216 & 396760,60747 & $8,1844 * *$ \\
Residue-a $^{2}$ & 33 & 1599761,05474 & 48477,60772 & \\
Plots & 47 & 6317331,67006 & & \\
Tb & 1 & 2827398,57240 & 2827398,57240 & $113,8182 * *$ \\
Int. Ta x Tb & 11 & 221794,74512 & 20163,15865 & $0,8117 \mathrm{~ns}$ \\
Residue-b & 36 & 894289,07075 & 24841,36308 & \\
Subplots & 95 & 10260814,05833 & & $454,9030 * *$ \\
Tc & 1 & 8004724,95299 & 8004724,95299 & $5,4424 * *$ \\
Int. Ta x Tc & 11 & 1053440,70177 & 95767,33652 & $22,0351 * *$ \\
Int. Tb x Tc & 1 & 387742,49107 & 387742,49107 & $0,7876 \mathrm{~ns}$ \\
Int. Ta x Tb x Tc & 11 & 152453,81092 & 13859,43736 & \\
Error & 72 & 1266951,96556 & 17596,55508 & \\
Total & 191 & 21126127,98064 & & \\
\hline $\mathrm{x}$ & & & & \\
\hline
\end{tabular}

$\overline{\mathrm{x}}=589,99567 \quad \mathrm{CV} \%-\mathrm{a}=37,32 \quad \mathrm{CV} \%-\mathrm{b}=26,71 \quad \mathrm{CV} \%-\mathrm{c}=22,48$

\footnotetext{
1Ta: Fixed factor A (genotypes); Tb: Fixed factor B (fungicide application); Tc: Fixed factor C (plant position). ${ }^{2}$ Resistance: Factor A residue (genotypes); Residue b: Residue of factor B (fungicide application); Residue-C: Residue of factor C (plant position). * FV: Source of variation; DF: Degrees of freedom; SS: sum of squares; MS: Mean square; F: Calculated F value. ** Significant at the $1 \%$ probability level $(\mathrm{p}<0.01)$
}

Acceptable experimental accuracy in severity assessment was observed, with coefficients of variation $(\mathrm{CV})$ close to $30 \%$ (Table 2). This value also depends on the inoculum dispersion by wind and rain, because inoculation was not carried out in a controlled manner. As a result, some bands may not have been infected in a delayed mode, which makes portions of genotypes somewhat uneven.
The significant interaction between Ta $\mathrm{x}$ Tc (genotype $\mathrm{x}$ plant position) may be related to differences in plant architecture as in large diameter geometric architectures makes less efficient fungicide deposition. The large number of leaves at the canopy intercepts the spray jet, not allowing the closer to the ground leaves receive direct application (DEBORTOLI et al., 2012). Furthermore, the 
microclimate becomes more favorable because it prevents the solar radiation action at the lower third of the plants (FURTADO et al., 2009). Thus, an estimation of genotypes agronomic parameters is necessary when analyzing soybean rust severity. The significant interaction between $\mathrm{Tb} \mathrm{x} T \mathrm{~T}$ (fungicide $\mathrm{x}$ plant position) shows that the relation formed by plant architecture and severity can actually has influence.

During the crop development, favorable climate contributed to pathogen development and showed satisfactory rates of severity in the evaluations. The first occurrence of rust in the area in the 2015/2016 season was dated February 15, 2015, in soybean (R1 stage), reported by the Antirust Consortium (CONSORCIO ANTIFERRUGEM, 2017). Thus, due to late date sowing, monitoring started in vegetative stage V1. The first soybean rust focus in the area was confirmed 50 days after emergence (DAE), at the beginning of the flowering of most of the plots, and the first evaluation of the severity and the application of the fungicide were carried out.

The strains showed contrast with the susceptible commercial pattern (BRX DESAFIO 8473 RSF), and differed from each other, thereby indicating the presence of horizontal resistance classes. This type of resistance is also known as partial, incomplete or qualitative (PARLEVLIET, 1979).

Analyzing the AUDPC results of lower third in the sub-plot with fungicide (Table 4), the genotype resistant standard LAGER-216 (664.79) was statistically overcome by LAGER-166, LAGER-104, LAGER-210 and LAGER-279. The same result was not seen in other LAGER-216 evaluations. Specifically, this result could have been obtained due to interaction genotype $\mathrm{x}$ plant position and fungicide $\mathrm{x}$ plant position, with negative influence for soybean rust resistance. Therefore, the leaf canopy may have influenced the application of the fungicide, because when it is not applied the genotype maintains resistance equivalent or superior to the others. The lower values of AUDPC found in fungicide application in comparison to no application are corroborated by both photosynthetic rate and decrease of the cellular respiration, generating greater mass production and consequently productivity (ALVES, 2016). The effects of photosynthetic loss are also the cause of differentiation. According to Calaça (2007), there is a negative relation between the absorption of healthy leaf area and soybean yield, caused by the fungus. This leads to consider the importance of preventive control with the use of systemic fungicides, allied with genetic resistance. Genotypes with partial resistance present lower number of pustules per leaf, as well as minor injuries resulting in a lower inoculum source (SANTOS et al., 2007). Genotypes that are more resistant to leaf severity are important for reducing the amount of fungicide applications.

According to Yorinori, Nunes-Júnior and Lazzarotto (2004), the onset of fungus infection occurs in plants lower portions. The results found in this study corroborate this statement, since there was a delay of disease development, in the R1 stage, at the middle third portion in relation to the lower third portion, which directly reflected in the results of severity in the other evaluations and consequently in AUDPC (Table 3).

Analyzing the overall averages of the genotypes for AUDPC (Table 4) is possible to note the horizontal resistance, because various levels of severity were found. In addition, a large number of promising materials for resistance as LAGER-210 $(333,19)$. Some other genotypes were also important, with AUDPC averages significantly lower than the breeding program resistant genotype: LAGER-218 (535.52), LAGER-166 (481.66), LAGER-268 (528.64) and LAGER -279 (490.83).

Table 3. Area under the disease progress curve (AUDPC) of soybean rust (Phakopsora pachyrhizi) in field conditions. Uberlândia-MG, 2016.

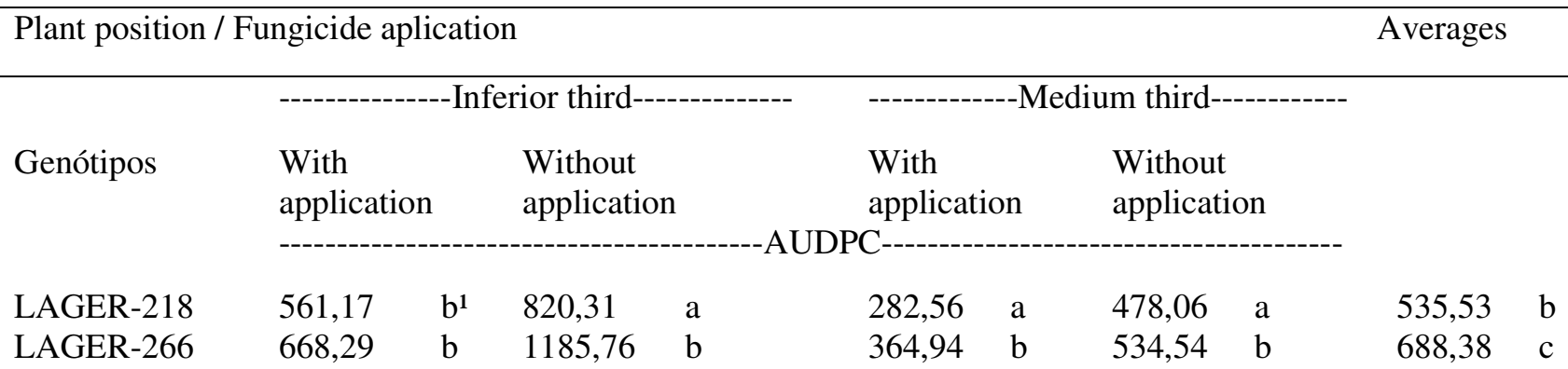

Biosci. J., Uberlândia, v. 35, n. 2, p. 398-408, Mar./Apr. 2019 


$\begin{array}{lllllllllll}\text { LAGER-144 } & 682,43 & \mathrm{~b} & 1017,41 & \mathrm{a} & 342,10 & \mathrm{~b} & 435,28 & \mathrm{a} & 619,31 & \mathrm{c} \\ \text { LAGER-166 } & 459,65 & \mathrm{a} & 883,86 & \mathrm{a} & 205,06 & \mathrm{a} & 378,06 & \mathrm{a} & 481,66 & \mathrm{~b} \\ \text { LAGER-104 } & 510,57 & \mathrm{a} & 929,92 & \mathrm{a} & 338,06 & \mathrm{~b} & 597,03 & \mathrm{~b} & 593,90 & \mathrm{c} \\ \text { LAGER-203 } & 701,79 & \mathrm{~b} & 1134,28 & \mathrm{~b} & 305,74 & \mathrm{~b} & 431,93 & \mathrm{a} & 643,44 & \mathrm{c} \\ \text { LAGER-224 } & 702,71 & \mathrm{~b} & 1027,31 & \mathrm{a} & 321,62 & \mathrm{~b} & 405,02 & \mathrm{a} & 614,17 & \mathrm{c} \\ \text { LAGER-268 } & 667,42 & \mathrm{~b} & 784,35 & \mathrm{a} & 242,26 & \mathrm{a} & 420,54 & \mathrm{a} & 528,64 & \mathrm{~b} \\ \text { LAGER-210 } & 311,89 & \mathrm{a} & 557,72 & \mathrm{a} & 181,78 & \mathrm{a} & 281,38 & \mathrm{a} & 333,19 & \mathrm{a} \\ \text { LAGER-279 } & 422,41 & \mathrm{a} & 763,38 & \mathrm{a} & 352,32 & \mathrm{~b} & 425,21 & \mathrm{a} & 490,83 & \mathrm{~b} \\ \text { LAGER-216 } & 664,79 & \mathrm{~b} & 877,03 & \mathrm{a} & 291,83 & \mathrm{a} & 393,09 & \mathrm{a} & 556,69 & \mathrm{c} \\ \text { DESAFIO } & 1181,57 & \mathrm{c} & 1544,32 & \mathrm{c} & 484,54 & \mathrm{c} & 766,55 & \mathrm{c} & 994,25 & \\ 84732 & & & & & & & & & & \mathrm{~d}\end{array}$

${ }^{1}$ Averages followed by the same letter in the column do not differ statistically between each other. The Scott-Knott test was applied at a 0.05 significance level. ${ }^{2}$ BRASMAX CHALLENGE 8473 RSF.

According to the $\mathrm{F}$ test, at 0.05 significance level, significant statistical differences for the characters were observed: number of days and plant height at flowering, and insertion height of the first pod (Table 4). There were no significant differences between genotypes in the experiment for both PHM and NDM (Table 5). According to the number of days to flowering (NDF) average test, LAGER-144, LAGER-210 and LAGER-268 genotypes presented a longer juvenile period in relation to others, flourishing beyond 50 days after emergency (Table 4). Soybean plants require a minimum period of 42 to 58 days to flowering for a minimum biomass production that provides acceptable grain yield. Flowering time differences among genotypes at the same sowing are mainly due to the specific response of these materials to day duration (EMBRAPA, 2014). The juvenile period, according to Camara et al. (1998), a period in the plant cycle which still favorable environmental conditions, the plant is not induced to flowering. Thus, very early flowering suggests a short juvenile period, making the genotype more sensitive to sowing time variations.

Regarding the variable plant height at flowering, the LAGER-218, LAGER-279 and RSF 8473 BRASMAX DESAFIO genotypes obtained the smaller plant heights. Other materials showed positive performance in terms of the studied variable when compared to the work of Barros et al. (2011), where genotypes at the same local, but with two fungicides applications showed values between 30 and $40 \mathrm{~cm}$. It is recommended that at this stage the plants measure at least $50 \mathrm{~cm}$ or that the canopy is already completely covering the soil (CAMARA et al., 1998). Significantly lower values of plant height in flowering can generate lower grain yield due to lower photosynthetic area. However, it avoids damage due to lodging and the lower severity incidence through unfavorable microclimate.

A reasonable experimental precision was observed for the study of productivity, with coefficient of variation (CV) slightly above of $30 \%$. The characteristic is influenced by several intrinsic factors such as plant density and harvest. The plants was manually harvested, however, the transport equipment to the shed and the pods tracks machine may have led to some losses. The yield CV in the sub-plot without fungicide obtained $34.05 \%$, the fungicide subplot of $40.11 \%$ and the average experiment yield of $32.81 \%$ (Table 5). Thus, with yield data was possible to evaluate the more productive genotypes. As the breeding programs seek for high yield, it was conducted the choice of materials that responded positively to yield, both with fungicide, as without fungicide. 
Table 4. Average evaluation of number of days to flowering, plant height at flowering, number of days to maturation, plant height at maturation and insertion height of the first pod by LAGER-UFU soybean genotypes

\begin{tabular}{|c|c|c|c|c|c|c|c|c|c|c|}
\hline \multirow{2}{*}{$\begin{array}{l}\text {--Genótipos--- } \\
\text { LAGER-218 }\end{array}$} & \multicolumn{2}{|c|}{-----NDF (dias)*---- } & \multicolumn{2}{|c|}{-----PHF (dias)------- } & \multicolumn{2}{|c|}{------PHM (cm)------ } & \multicolumn{2}{|c|}{----NDM (cm)------ } & \multicolumn{2}{|c|}{-----IHFP (cm)-----. } \\
\hline & 41,00 & $\mathrm{a}^{1}$ & 23,00 & $\mathrm{~b}$ & 49,58 & $\mathrm{a}$ & 109,75 & $\mathrm{a}$ & 7,93 & $\mathrm{~b}$ \\
\hline LAGER-266 & 45,00 & $\mathrm{a}$ & 32,37 & $\mathrm{a}$ & 52,75 & $\mathrm{a}$ & 118,25 & $\mathrm{a}$ & 9,53 & $\mathrm{a}$ \\
\hline LAGER-144 & 50,50 & $\mathrm{~b}$ & 32,20 & $\mathrm{a}$ & 45,28 & $\mathrm{a}$ & 122,25 & $\mathrm{a}$ & 8,58 & $\mathrm{a}$ \\
\hline LAGER-166 & 46.00 & $\mathrm{a}$ & 31.70 & $\mathrm{a}$ & 45,65 & $\mathrm{a}$ & 113,89 & $\mathrm{a}$ & 8,88 & $\mathrm{a}$ \\
\hline LAGER-104 & 47,00 & $\mathrm{a}$ & 33,73 & $\mathrm{a}$ & 40,00 & $\mathrm{a}$ & 112,50 & $\mathrm{a}$ & 7,25 & $\mathrm{~b}$ \\
\hline LAGER-203 & 56,50 & $\mathrm{~b}$ & 34,95 & $\mathrm{a}$ & 66,50 & $\mathrm{a}$ & 145,00 & $\mathrm{~b}$ & 9,28 & $\mathrm{a}$ \\
\hline LAGER-224 & 41,50 & $\mathrm{a}$ & 35,60 & $\mathrm{a}$ & 48,90 & $\mathrm{a}$ & 121.95 & $\mathrm{a}$ & 8,26 & $\mathrm{a}$ \\
\hline LAGER-268 & 50,50 & $\mathrm{~b}$ & 32,38 & $\mathrm{a}$ & 37,63 & $\mathrm{a}$ & 117.25 & $\mathrm{a}$ & 7,25 & $\mathrm{~b}$ \\
\hline LAGER-210 & 52,00 & $\mathrm{~b}$ & 32,20 & $\mathrm{a}$ & 38,63 & $\mathrm{a}$ & 111.50 & $\mathrm{a}$ & 7,13 & $\mathrm{~b}$ \\
\hline LAGER-279 & 44,00 & $\mathrm{a}$ & 26,50 & $\mathrm{~b}$ & 50,60 & $\mathrm{a}$ & 123.61 & $\mathrm{a}$ & 8,80 & $\mathrm{a}$ \\
\hline LAGER-216 & 46,25 & $\mathrm{a}$ & 31,80 & $\mathrm{a}$ & 50,03 & $\mathrm{a}$ & 113.25 & $\mathrm{a}$ & 7,28 & $\mathrm{~b}$ \\
\hline DESAFIO 84732 & 41,75 & $\mathrm{a}$ & 21,73 & $\mathrm{~b}$ & 48,23 & $\mathrm{a}$ & 109.25 & $\mathrm{a}$ & 8,20 & $\mathrm{a}$ \\
\hline$\overline{\mathrm{X}}$ & 46,91 & & \multicolumn{2}{|c|}{30,58} & 47,81 & & 118,20 & & 8,19 & \\
\hline $\mathrm{CV}(\%)$ & 13,98 & & 11,56 & & 13,69 & & 11,58 & & \multicolumn{2}{|c|}{11,86} \\
\hline
\end{tabular}


Table 5. Evaluation of yield by LAGER-UFU soybean genotypes

\begin{tabular}{|c|c|c|c|c|c|c|}
\hline \multirow[t]{2}{*}{ Genotypes } & \multicolumn{6}{|c|}{ 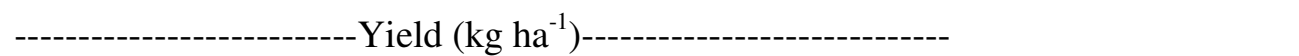 } \\
\hline & \multicolumn{2}{|c|}{-----With fungicide----- } & \multicolumn{2}{|c|}{--Without fungicide--- } & \multicolumn{2}{|c|}{-----Average----- } \\
\hline LAGER-218 & 1324,64 & $\mathrm{a}$ & 777,61 & $\mathrm{~b}$ & 1051,12 & \\
\hline LAGER-266 & 1017.41 & $\mathrm{a}$ & 1219,74 & $\mathrm{~b}$ & 1118.57 & $\mathrm{~b}$ \\
\hline LAGER-144 & 612,20 & $\mathrm{~b}$ & 1315,66 & $\mathrm{~b}$ & 963,93 & $\mathrm{~b}$ \\
\hline LAGER-166 & 881,03 & $\mathrm{~b}$ & 908,33 & $\mathrm{~b}$ & 894,68 & $\mathrm{~b}$ \\
\hline LAGER-104 & 1369,91 & $\mathrm{a}$ & 2020,73 & $\mathrm{~b}$ & 1695,31 & $\mathrm{a}$ \\
\hline LAGER-203 & 473,45 & $\mathrm{~b}$ & 2085,87 & $\mathrm{~b}$ & 1279,66 & $\mathrm{~b}$ \\
\hline LAGER-224 & 856,22 & $\mathrm{~b}$ & 1159,96 & $\mathrm{~b}$ & 1008,08 & $\mathrm{~b}$ \\
\hline LAGER-268 & 722,50 & $\mathrm{~b}$ & 1532,56 & $\mathrm{~b}$ & 1127,52 & $\mathrm{~b}$ \\
\hline LAGER-210 & 1117,13 & $\mathrm{a}$ & 3419,05 & $\mathrm{a}$ & 2268,08 & $\mathrm{a}$ \\
\hline LAGER-279 & 1100,00 & $\mathrm{a}$ & 1706,41 & $\mathrm{~b}$ & 1403,20 & $\mathrm{~b}$ \\
\hline LAGER-216 & 1540,01 & $\mathrm{a}$ & 2863,46 & $\mathrm{a}$ & 2201,73 & $\mathrm{a}$ \\
\hline DESAFIO $^{2}$ & 685,45 & $\mathrm{~b}$ & 2006,69 & $\mathrm{~b}$ & 1346,07 & $b$ \\
\hline$\overline{\mathrm{x}}$ & 974,99 & & 1751,34 & & 1363,16 & \\
\hline CV\% & 34,05 & & 40,11 & & 32,81 & \\
\hline
\end{tabular}

${ }^{1}$ Averages followed by the same letter in the column do not differ statistically between each other. The Scott-Knott test was applied at a 0.05 significance level. ${ }^{2}$ BRASMAX CHALLENGE 8473 RSF.

Therefore, the LAGER-104, LAGER-210, LAGER-216 materials were the most productive and the LAGER-104 material was the most tolerant because it presented lower levels of losses compared to the others.

The standard genotype LAGER-216 resistant to soybean rust showed tolerance because even when they were higher than the severity values, when all were treated with fungicides, productivity responded well (2863.46 $\mathrm{kg}$ ha-1), higher to the overall average fungicide $(1751.34 \mathrm{~kg}$ ha-1). This makes this material agronomically superior to others, since the fungicide application is usually necessary. The LAGER-210 genotype performance is also highlighted, as it was the genotype that presented low levels of soybean rust severity in all of subplots and also presented the highest yield level of $3419.05 \mathrm{~kg}$ ha-1, when applied fungicide.

Table 6 shows the Pearson correlation coefficient (r) as variables analyzed, indicating the degree and direction (positive or negative) correlations. Although negatively correlated variables area under the disease progress curve and grain yield (AUDPC*PROD) were not significant at 0.05 probability. Some variables were positively correlated as NDM*PHM, IHFP*PHM.

Although late lineages with reduced disease development rates do not present basic restrictions for their development due to non-formation of segregating populations, there is a difficulty in evaluating genotypes with different maturation periods. Besides the physiological peculiarities of each one, there are environmental character differences because the plants mature in different periods of time (BROGIN, 2005). The significant positive correlation between AUDPC*NDM (Table 6) goes against it, indicating that most disease severity in leaf area is correlated with longer plant maturation days. Over time the lesions increase in size and amount of injuries, as the disease is polycyclic the ill plants within the experiment can be an inoculum source. In addition, in the present study rainfall was well distributed, which resulted in a favorable microclimate (environmental factor), besides maintaining the host longer in the field (host factor), thus causing more pathogen life cycles in the plant. This results in less escape for late plants, which makes handling more difficult. This fact is relevant to breeding programs. 
Table 6. Pearson's simple correlation coefficient (r) and probability (\%) by T-Test between agronomic variables of 12 early cycle genotypes - LAGER UFU

\begin{tabular}{|c|c|c|c|c|c|c|c|}
\hline & AUDPC & YIELD & NDM & PHM & NDF & PHF & IHFP \\
\hline \multirow[t]{2}{*}{ AUDPC } & & $-0.2948^{1}$ & 0.0201 & 0.3261 & -0.3346 & -0.3623 & 0.3047 \\
\hline & & $64.5625^{2}$ & 94.9015 & 30.1704 & 31.5701 & 27.3398 & 33.7464 \\
\hline \multirow[t]{2}{*}{ YIELD } & & & -0.2422 & -0.2099 & 0.2276 & 0.1033 & $-0.6147 *$ \\
\hline & & & 54.6781 & 51.846 & 75.9134 & 50.6628 & 3.2249 \\
\hline \multirow[t]{2}{*}{ NDM } & & & & 0.732 & 0.4775 & 0.4775 & 0.569 \\
\hline & & & & 0.6724 & 5.5185 & 13.4781 & 5.1633 \\
\hline \multirow[t]{2}{*}{ PHM } & & & & & 0.1217 & 0.0223 & 0.7089 \\
\hline & & & & & 72.0486 & 94.6569 & $0.9656^{* *}$ \\
\hline \multirow[t]{2}{*}{ NDF } & & & & & & 0.5736 & 0.0076 \\
\hline & & & & & & 6.2995 & 98.0086 \\
\hline \multirow[t]{2}{*}{ PHF } & & & & & & & 0.0019 \\
\hline & & & & & & & 99.1342 \\
\hline
\end{tabular}

IHFP

\begin{abstract}
${ }^{1}$ Pearson's simple correlation coefficient (r); ${ }^{2}$ probability (\%) by the T Test; *: significance at 0.05 by the t-test; **: significant at 0.01 probability by t-test. AUDPC: Area under the disease progress curve; Yield: Grain produtivity; NDF: Number of days to flowering; PHF: Plant height at flowering; NDF: Number of days to maturation; PHM: Plant height at maturation; IHFP: Insertion height of the first pod.
\end{abstract}

\section{CONCLUSION}

LAGER-210 and LAGER-216 genotypes were selected for cultivation and value and usage studies (VUSs) because they showed partial resistance to rust, short cycle, good morphoagronomic characteristics and higher yields. In the future, these lineages will lead to cultivars that may be recommended for certain regions and reduce dependence on fungicide applications.

\section{ACKNOWLEDGMENTS}

The authors acknowledge Fundação de Amparo à Pesquisa do estado de Minas Gerais (FAPEMIG), Conselho Nacional de Desenvolvimento Tecnológico (CNPq) and Coordenação de Aperfeiçoamento de Pessoal de Nível Superior of Brazil (CAPES) for financial supports.

RESUMO: A soja, mesmo com a evolução tecnológica, não atingiu ainda uma média de produção no Brasil de $4.000 \mathrm{~kg} \mathrm{ha}^{-1}$. Isto é devido aos fatores climáticos, nutricionais, genéticos e fitossanitários. Dentre eles está a doença ferrugem-asiática da soja, causada pelo fungo Phakopsora pachyrhizi Syd. \& Syd., uma das mais severas, com danos de até $100 \%$. Dentre as estratégias de manejo estão o uso de genótipos precoces, uso de fungicidas de forma preventiva e cultivares com resistência parcial ao fitopatógeno. Para a obtenção de cultivares resistentes, seis genes dominantes, que condicionam a resistência vertical (qualitativa), já foram relatados na literatura, mas a estabilidade desse tipo de resistência não é durável. Portanto, a identificação de genótipos que possam ser utilizados como fontes de resistência horizontal (quantitativa) é primordial para aumentar a longevidade das cultivares lançadas no mercado brasileiro. Este trabalho teve como objetivo avaliar a resistência de 12 genótipos de soja frente ao patógeno e respostas à produtividade. $\mathrm{O}$ presente trabalho foi desenvolvido na Fazenda do Glória, na Universidade Federal de Uberlândia (UFU), localizada no município de Uberlândia, MG, Brasil. No ano agrícola 2015/2016 foi conduzido um experimento com subparcelas com ou sem fungicida Azoxistrobina + Benzovindiflupyr e subsubparcelas relacionadas à posição de avaliação na planta. Foram 12 genótipos de ciclo precoce, sendo 10 provenientes do laboratório de germoplasma da UFU (LAGER), uma testemunha comercial suscetível e uma testemunha do LAGER conhecidamente resistente, delineados em blocos casualizados, com quatro repetições. As parcelas experimentais foram representadas por duas fileiras de $6 \mathrm{~m} \times 0,5 \mathrm{~m}$, sendo que a área útil de $2,5 \mathrm{~m}^{2}$ constituiu-se pelas duas fileiras centrais, eliminando-se $0,5 \mathrm{~m}$ em cada extremidade da parcela. Os genótipos LAGER-210 e LAGER-216 foram selecionados para estudos de valor de cultivo e uso (VCU) por apresentarem resistência parcial à ferrugem, ciclo curto, boas características morfoagronômicas e maiores produtividades. 
PALAVRAS CHAVE: Glycine max (L.) Merrill. Melhoramento de Soja. Phakopsora pachyrhizi. Controle genético

\section{REFERENCES}

AKAMATSU, H.; YAMANAKA, N.; YAMAOKA, Y.; SOARES, R. M.; MOREL, W.; IVANCOVICH, A. J. G.; BOGADO, A. N.; KATO, M.; YORINORI, J. T.; SUENAGA, K. Pathogenic diversity of soybean rust in Argentina, Brazil, and Paraguay. Journal of general plant pathology, [S.1.], v. 79, n. 1, p. 28-40, 2013.

ALVES, V. M. Fungicidas protetores no manejo da ferrugem da soja, processos fisiológicos e produtividade da cultura. Dissertação (Mestrado em Agronomia) - Universidade Federal de Uberlândia, Uberlândia, 2016.

BARROS, L. S.; POLIZEL, A. C.; SOLINO, A. J. da S.; RUDNICK, V. A. de S. Genótipos de soja de ciclo semi precoce/médio quanto à doenças fúngicas foliares e caracteres agronômicos. Encicloplédia biosfera, Goiânia, v. 7, n. 12, 2011.

BROGIN, R. L. Mapeamento de genes de resistência a ferrugem e de qtls envolvidos na resistência a Septoriose em soja. Tese (Doutorado em Agronomia) - Universidade de São Paulo. Piracicaba, 2005.

CALAÇA, H. A. Ferrugem asiática da soja: relações entre o atraso do controle químico, rendimento, severidade e área foliar sadia de soja (Glycine max L. Merril). Tese (Doutorado em Agronomia) Universidade de São Paulo. Piracicaba, p. 80. 2007.

CÂMARA, G. M. S.; PIEDADE, S. M. S.; MONTEIRO, J. H.; GUERZONI, R. A. Desempenho vegetativo e produtivo de cultivares e linhagens de soja de ciclo precoce no município de Piracicaba-SP. Scientia Agricola, Piracicaba, v. 55, n. 3, p. 403-412, 1998. https://doi.org/10.1590/S0103-90161998000300008

CARNEIRO, L. C. Caracterização epidemiológica da resistência parcial e análise da tolerância de genótipos de soja à ferrugem asiática. Tese (Doutorado em Agronomia) - Universidade de São Paulo. Piracicaba, p. 75. 2007.

COMPANHIA NACIONAL DE ABASTECIMENTO - CONAB. Análise das culturas. Acompanhamento da safra brasileira grãos, Brasília, v. 4, Safra 2016/17 - Décimo primeiro levantamento, p. 58-136, ago. 2017. Disponivel em:

<http://www.conab.gov.br/OlalaCMS/uploads/arquivos/17_08_10_11_27_12_boletim_graos_agosto_2017.pdf >. Acesso em: 04 abr. 2017.

CONSORCIO ANTIFERRUGEM. Consorcio Antiferrugem, 2017. Disponivel em: $<$ http://www.consorcioantiferrugem.net>. Acesso em: 30 jan. 2017.

CRUZ, C. D. Genes: a software package for analysis in experimental statistics and quantitative genetics. Acta Scientiarum. Agronomy, v. 35, n. 3, p. 271-276, 2013. https://doi.org/10.4025/actasciagron.v35i3.21251

DALlA LANA, F.; ZIEGELMANN, P. K.; MAIA, A. H. N., GODOY, C. V.; DEL PONTE, E. M. Metaanalysis of the relationship between crop yield and soybean rust severity. Phytopathology, St. Paul, v. 105, n. 3, p. 307-315, 2015.

DEBORTOLI, M. P.; TORMEN, N. R.; BALARDIN, R. S.; FAVERA, D. D.; STEFANELLO, M. T., PINTO, F. F.; UEBEL, J. D. Espectro de gotas de pulverização e controle da ferrugem-asiática-da-soja em cultivares com diferentes arquiteturas de planta. Pesquisa Agropecuária Brasileira, Brasilia, v. 47, n. 7, julho 2012.

EMPRESA BRASILEIRA DE PESQUISAS AGROPECUÁRIAS - EMBRAPA. Tecnologias de Produção de Soja - Região Central do Brasil 2014. Londrina: Embrapa Soja, 2014. 262 p. 
FEHR, W. R.; CAVINESS, C. E. Stages of soybean development. Ames: Iowa State University of Science and Technology, 1977.

FURTADO, G. Q.; ALVES, S. A. M. ; GODOY, C. V; SALATINO, M. L. F.; MASSOLA JÚNIOR, N. S. Influência da luminosidade e da camada de cera epicuticular de superfícies de folhas de soja na infecção de Phakopsora pachyrhizi. Tropical Plant Pathology, Viçosa, v. 34, n. 5, p. 306-312, 2009.

KATO, M.; YORINORI, J. T. A study on a race composition of Phakopsora pachyrhizi in Brazil: a difficulty of race identification. JIRCAS Working Report, n. 58, p. 94-98, 2008.

LI, S.; SMITH, J. R.; RAY, J. D.; FREDERICK, R. D. Identification of a new soybean rust resistance gene in PI 567102B. Theoretical and Applied Genetics, v. 125, n. 1, p. 133-142, 2012.

https://doi.org/10.1007/s00122-012-1821-y

PARLEVLIET, J. E. Components of resistance that reduce the rate of epidemic development. Annual Review of Phytopathology, Palo Alto, v. 17, p. 203-22, 1979. https://doi.org/10.1146/annurev.py.17.090179.001223

POLIZEL, A. C.; JULIATTI, F. C. Quantificação de doenças foliares da soja por escalas diagramáticas. Enciclopédia Biosfera, v. 6, n. 11, 2010.

SANTOS, J. A.; JULIATTI, F. C.; SANTOS, V. A.; POLIZEL, A. C.; JULIATTI, F. C.; HAMAWAKI, O. T. Caracteres epidemiológicos e uso da análise de agrupamento para resistência parcial à ferrugem da soja.

Pesquisa Agropecuária brasileira, v. 42, n. 3, 2007.

SCHWERZ, L. A.; WERLANG, T.; PETRY, S.; LUZ, A. C.; POZZO, V. C.; COSSA, G. E.; TIRONI, S. P. Severidade da ferrugem asiática na soja em relação à aplicação de fungicidas. Anais do SEPE-Seminário de Ensino, Pesquisa e Extensão da UFFS, v. 6, n. 1, 2016.

SEIXAS, C. D. S.; GODOY, C. V. Vazio sanitário: panorama nacional e medidas de monitoramento. In: SIMPÓSIO BRASILEIRO DE FERRUGEM ASIÁTICA, 1, 2007. Anais... Londrina: EMBRAPA SOJA, 2007.

SHANNER, G.; FINLEY, R. F. The effects of nitrogen fertilization on the expression. Phytopathology, St. Paul, v. 70, p. 1183-86, 1977.

SILVA, F. A. S.; AZEVEDO, C. A. V. The Assistat Software Version 7.7 and its use in the analysis of experimental data. African Journal of Agricultural Research, v. 11, n. 39, p. 3733-3740, 2016. https://doi.org/10.5897/AJAR2016.11522

YORINORI, J. T.; LAZZAROTTO, J. J. Situação da ferrugem asiática da soja no Brasil e na América do Sul. Londrina: EMBRAPA/CNPSO, 2004. 27 p. (Documentos, n. 236).

YORINORI, J. T.; NUNES JÚNIOR, J.; LAZZAROTTO, J. J. Ferrugem asiática da soja no Brasil: evolução, importância econômica e controle. Londrina: EMBRAPA/CNPSO, 2004. 36 p. 